\title{
Economic profitability analysis of the use of zeolite sorbents in mercury removal technologies
}

ABSTRACT: Mercury emissions have become one of the problems in the energy sector in recent years. The currently used mercury removal techniques include: primary, secondary and preliminary methods. However, due to the large variation in the mercury content in hard and brown coal and the different characteristics of power plants, these methods are often not effective enough to meet the new requirements set by BREF/BAT which requires a search for new, high-efficiency solutions. The proposal for a new technology has been developed in the project "Hybrid Adsorption Systems to Reduce Mercury Emissions Using Highly Effective Polymer Components" (HYBREM). The project was implemented by the consortium of SBB Energy SA and ZEPAK Pątnów II Power Plant. An innovative, high-efficiency hybrid technology for purifying exhaust gases from mercury was developed. GORE polymer modules were used as a technology base where, in combination with the injection of solid sorbents, a hybrid technology was developed. To assess the economic efficiency of the similar case as in the HYBREM project model based on OPEX and CAPEX, each method was selected separately. The article focused on the substitution of solid sorbents used in the HYBREM

$\triangle$ Corresponding Author: Magdalena Wdowin; e-mail: wdowin@meeri.pl

${ }^{1}$ Mineral and Energy Economy Research Institute, Polish Academy of Sciences, Kraków, Poland; e-mail: rkoneczna@min-pan.krakow.pl

2 SBB Energy SA, Poland; e-mail: r.zmuda@sbbenergy.com

3 SBB Energy SA, Poland; ORCID iD: 0000-0002-3414-5123; e-mail: 1.lelek@sbbenergy.com

${ }^{4}$ Mineral and Energy Economy Research Institute, Polish Academy of Sciences, Kraków, Poland; ORCID iD: 0000-0002-5097-719X; e-mail: wdowin@meeri.pl

2020. The Author(s). This is an open-access article distributed under the terms of the Creative Commons Attribution-ShareAlike International License (CC BY-SA 4.0, http://creativecommons.org/licenses/by-sa/4.0/), which permits use, distribution, and reproduction in any medium, provided that the Article is properly cited. 
project by zeolite based materials. Modified zeolite X, applied in the project, was derived from fly ash. Preliminary analysis shows that the system of proposed technologies is very cost-competitive compared only to GORE technology. The basic factors are the possibility of recovering zeolites from ash, combined with low investment outlays.

KEYWORDS: mercury removal technologies, economic analysis, case study, investment cost, operating expenditures

\section{Introduction}

Mercury ( $\mathrm{Hg}$ ), due to its high toxicity, causes significant environmental and health damage, making its emission a significant risk (IPCS 2000). Its emissions to the atmosphere come mainly from industrial processes, including the combustion of fuels like hard and brown coal at stage of energy production processes (UNEP 2013).

$\mathrm{Hg}$ from industrial processes (by-product emission) are released as accompanying emissions in production processes, where mercury constitutes a by-product related to its occurrence in fuels and raw materials such as metal ores (Pacyna et al. 2010). The highest share in Hg global emissions comes from the combustion of coal, industrial and household sectors, which represents about $45 \%$ of total anthropogenic mercury emissions. Another important source are cement, iron, steel and non-ferrous metals production processes. In 2018, Poland took second place among European countries in the volume of anthropogenic emission of mercury into the air (EEA 2018).

The main EU instrument regulating emissions from industrial installations is Directive 2010/75/EU of the European Parliament and of the Council on industrial emissions (IED). It is a combination of the IPPC Directive 96/61/EC and the Directives on large combustion sources (2000/76/EC) as well as waste incineration (2001/80/EC). Additionally in accordance with the requirements of Directive 2008/1/EC, industrial installations have to meet the requirements of the Best Available Techniques (BAT).

With reference to the above a comprehensive approach to problems arising from the operation of large industrial plants will be necessary. Activities related with significant negative environmental impacts, primarily in terms of mercury emissions to the atmosphere, must adapt to the new emission requirements. Additionally, these emissions should be continuously monitored especially for the combustion installations with a rated thermal input greater than $50 \mathrm{MW}$. This includes the electricity and heat generation sector as well as industries using conventional fuels.

Mercury content in coal is in relatively small amounts, however considering the stream of fuel burned at typical coal-fired power plant its emissions are significant, which in the world gives about $1500 \mathrm{Mg} /$ year. For countries such as Poland, were over $79 \%$ of electricity comes from fossil fuels constitutes a serious environmental and health risk (EPA 2020).

It should be noted that adapting the Polish energy sector to the requirements set by BREFs/BAT may involve high costs and will require the search for new, high-efficiency 
solutions. The currently used mercury removal techniques, i.e. primary, secondary and preliminary due to the large variation in the mercury content in hard and brown coal and the different characteristics of power plants these methods are often not effective enough to meet these requirements.

Therefore the subject of the analysis is a comparison of new technology developed under the project "Hybrid Adsorption Systems for Reducing Mercury Emissions Using Highly Effective Polymer Components" (HYBREM), with use of innovative solid sorbent. Under the above project the subjected technology was implemented by the SBB Energy SA and Pątnów II Power Plant consortium. An innovative, high-efficiency hybrid technology i.e. GORE polymer modules were used as a technology base in combination with the injection of solid sorbents for purifying exhaust gases from mercury gas forms was developed.

The object of the analysis is to examine the economic viability of an innovative hybrid technology that uses zeolite sorbents to remove $\mathrm{Hg}$ interchangeable with the previously used coal sorbents. Operational (OPEX) and capital expenditure (CAPEX) were used.

\section{Analysis of mercury emissions in Poland and in the world}

Global inventory of mercury emissions to air from anthropogenic sources in 2015 quantifies 2220 tones emission to 20 key sectors. Additional emission in range from tens to hundreds of tons per year may arise from smaller anthropogenic sources currently not detailed in this inventory (AMAP/UNEP 2018; Senior et al. 2000).

Gold mining primarily from South America, Sub-Saharan Africa is responsible for about $40 \%$ of the estimated Hg global emissions. The stationary combustion of fossil fuels and biomass $24 \%$ of the estimated global emissions, primarily from coal burning $(21 \%)$ is in second place. The main industrial sectors remain non-ferrous metal production (15\% of the global inventory), cement production (11\%) and ferrous metal production (2\%). Emissions from waste that includes mercury-added products comprise about $7 \%$ of the 2015 global inventory. Estimated global anthropogenic air emission of $\mathrm{Hg}$ was approximately $20 \%$ higher in 2015 than in 2010.

In the case of the $\mathrm{EU}, 39 \%$ of $\mathrm{Hg}$ emissions are related to the combustion of fossil fuels in the power sector and 23\% with energy used in industry (Fig. 1). However, in the years 1990-2015, these emissions fell by $74 \%$.

The countries with the highest mercury emissions share in EU (80\%) include: Poland, Germany, Italy, Greece, Spain, Great Britain, France, the Czech Republic and Romania. Compared to 2010, these emissions dropped in all countries except Lithuania, Luxembourg, Malta and Poland (Assessment of mercury... 2017).

In the last one, anthropogenic emissions are estimated at $11 \mathrm{Mg}$, of which $77 \%$ is caused by the combustion of solid fuels as (Wichliński et al. 2017), brown coal and hard coal (Lorez et al. 2007). The production of non-ferrous metals and cement are responsible for 1.8 $\mathrm{Mg}$ emission of $\mathrm{Hg}$ (Fig. 2). 


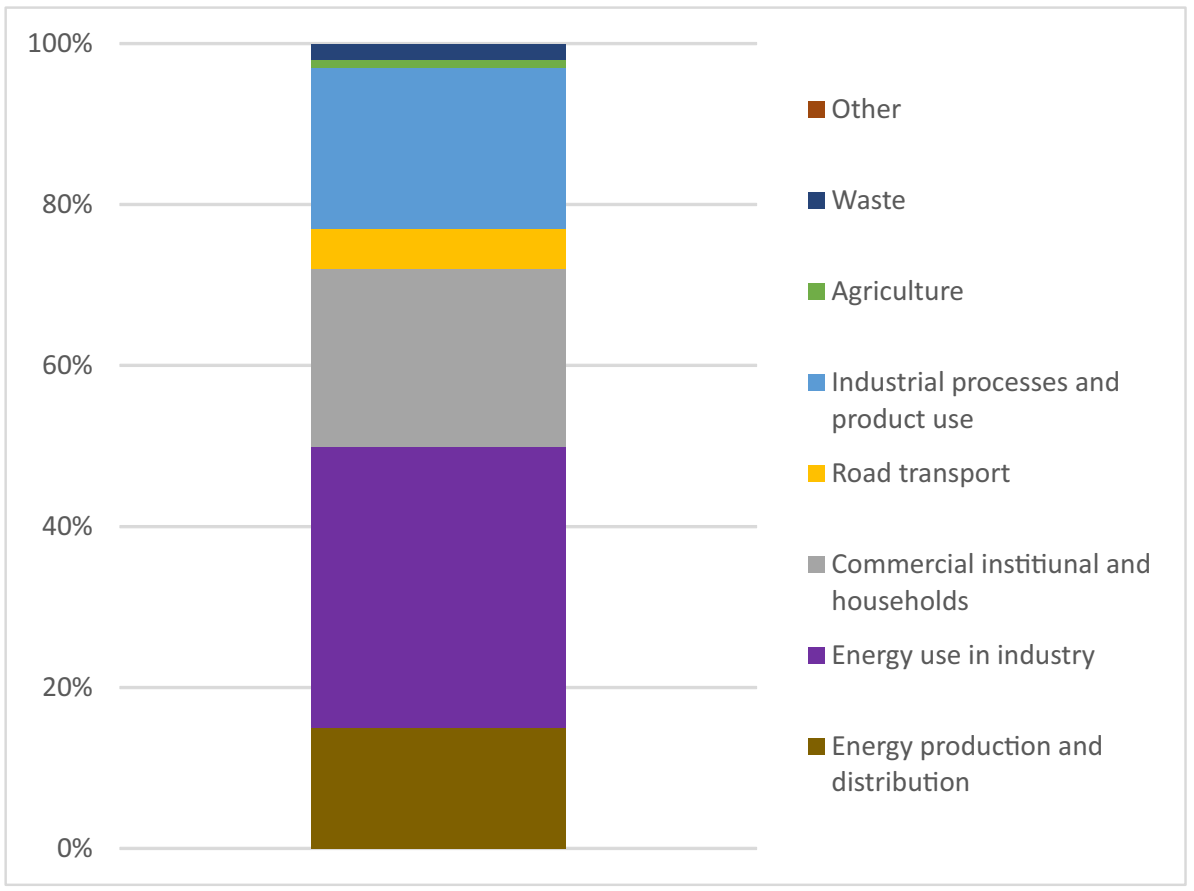

Fig. 1. Division of sectors emitting mercury in the European Union in 2016 (UNECE 2016)

Rys. 1. Podział sektorów emitujących rtęć w Unii Europejskiej w 2016 r.

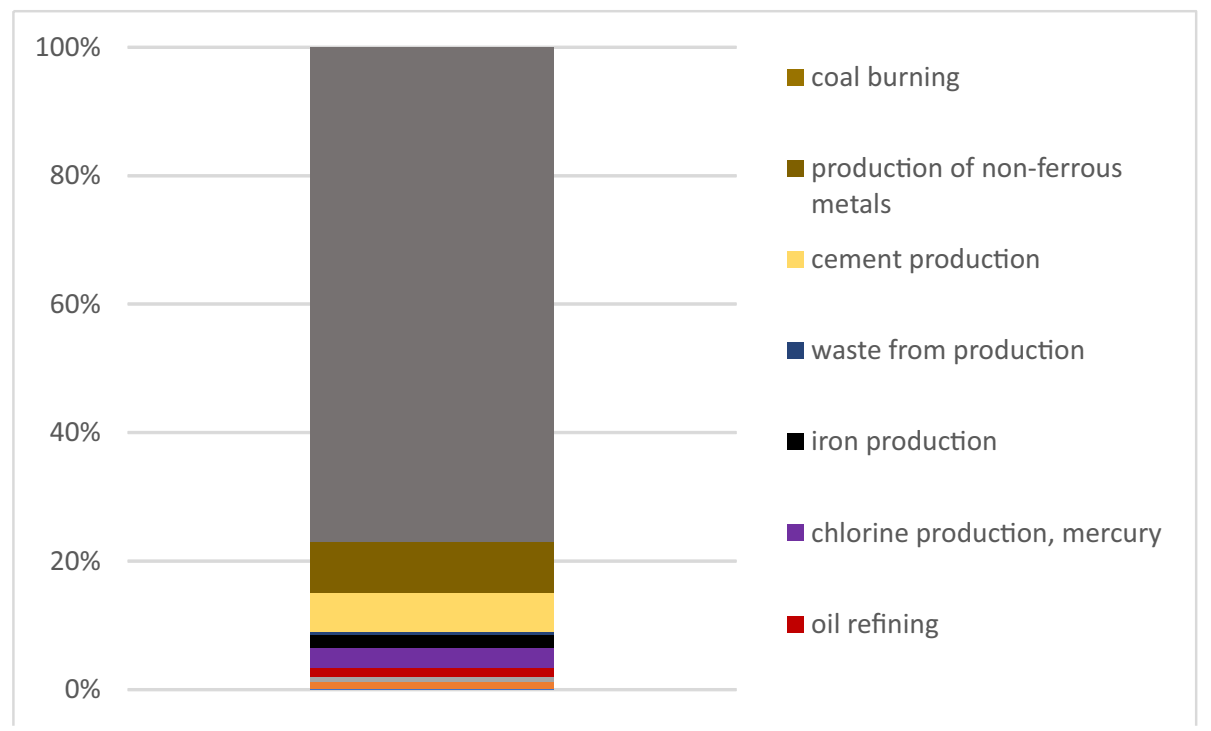

Fig. 2. Division of sectors emitting mercury in Poland in 2016 (LRTAP 2017)

Rys. 2. Podział sektorów emitujących rtęć w Polsce w 2016 r. 
In the years 1990-2015, mercury emissions fell from 14 to $11 \mathrm{Mg}$, with a $13 \%$ increase in 2015 compared to the previous year (Fig. 3).

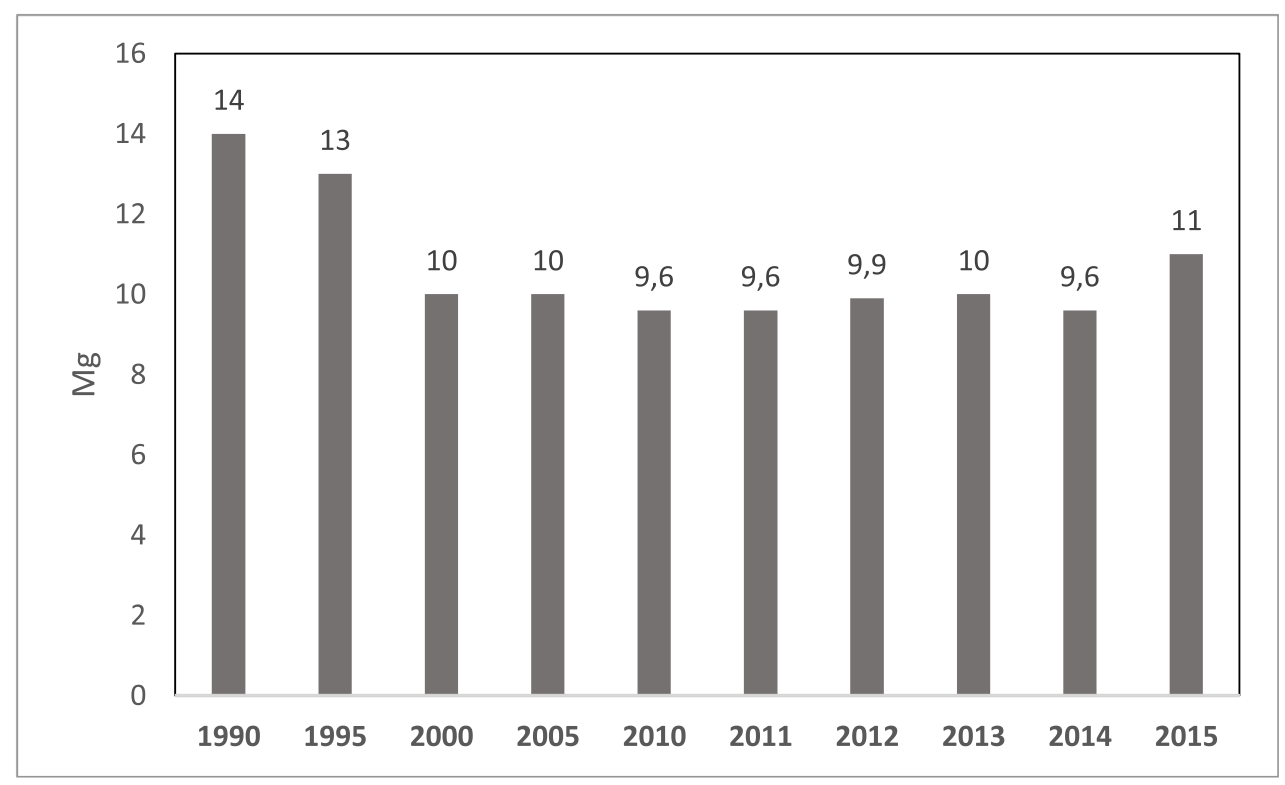

Fig. 3. Polish contributions to Hg emissions in the EU in 1990-2015 [in Mg] (LRTAP 2017)

Rys. 3. Wkłady Polski do emisji Hg w UE w latach 1990-2015 [Mg]

It is expected, that emissions in the EU, including Poland, will decrease in the coming years. Non-EU sources are predominant in global mercury emissions current and future global mercury emissions, although there are prospects for reducing global emissions in the nearest decades. In light of the new BAT/BREF regulations, which will become effective from 2021, mercury emissions from the energy sector are starting to play an increasingly important role.

\section{Mercury removal methods in power plants}

According to the Ministry of the Environment, the necessary modernization of the entire energy sector in Poland in the coming years - related with the BREF/BAT regulation is estimated to cost PLN 12 billion (Polish Electricity Committee 2018). Further investments in modernization resulting from the revision of these standards by the European Commission should also be included.

The currently used mercury removal techniques include primary methods consisting of removing mercury before the combustion process (pre-combustion), the secondary ones taking 
place after the combustion process (post-combustion), as well as the pretreatment method related with fuel treatment process (Żmuda et al. 2017).

The technology proposed by the GORE company is post-combustion method based on passive emission control of the exhaust gas on catalytic polymer material. It allows for $\mathrm{Hg}$ removal in the gas phase both in molecular and oxidized form, and in addition $\mathrm{SO}_{2}$ reduction (Żmuda et al. 2017). The technology is based on a patented polymer composite, its use does not require the injection of any chemical substance or additional sorbent. The concept of the installation operation is based on building the appropriate number of layers of polymer modules in the wet scrubber of the desulphurisation installation, behind the mist eliminators or in the gas duct from the absorber. The installation does not adversely affect combustion by-products, including fly ash and gypsum. On the surface of the composite, $\mathrm{SO}_{2}$ passes catalytically into liquid sulfuric acid, which is collected and neutralized in an existing wet scrubber (reactor). The structure and principle of operation of the technology is shown in Figure 4.

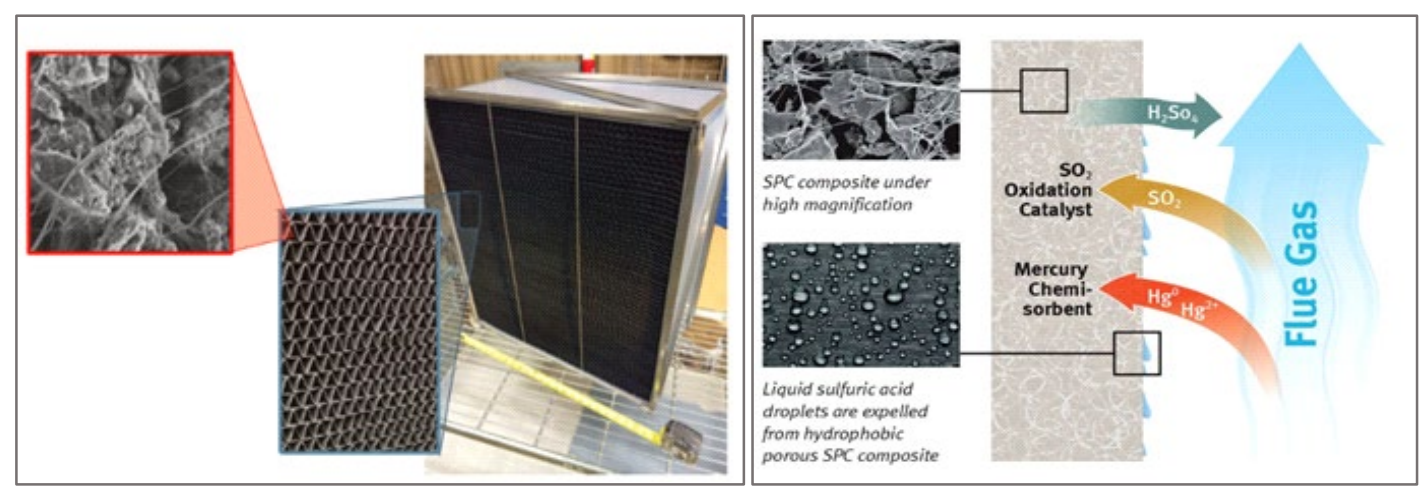

Fig. 4. GORE TM polymer modules and their surface reactions

Rys. 4. Moduły polimerowe firmy GORE ${ }^{\mathrm{TM}}$ oraz reakcje zachodzące na ich powierzchni

Since GORE's technology involves a high level of investment, in order to minimize it, it combining the technology with another representing lower CAPEX costs was decided. Therefore, GORE polymer modules are the basis of the technology, while the innovation is to combine them with the injection of solid sorbents to the flue gas duct, which contributes to higher emission reduction as well as cost effectiveness.

The pilot installation was built in order to develop technology under R\&D project (Fig. 5). Its location allowed conditions similar to those prevailing in the FGD installation to be obtained. The obtained test results allowed the scope of its performance depending on the variable parameters, i.e. mercury content in the fuel burned, $\mathrm{SO}_{2}$ share in the boiler exhaust gas, oxygen content, dust content in the fuel burned to be determined (Żmuda et al. 2017). In addition to polymer modules, the second part of the installation related with sorbent injection was located between the boiler house building and the ESP (Electrostatic Precipitator) installation and a flue gas channel 
before the rotary air preheater was selected for the location of the dosing points. The installation was operated using a forklift and big-bag sacks (Fig. 5). Under the pilot test two types of activated carbons impregnated with bromine compounds, two types of mineral sorbents, calcium sorbent as well as mixtures of these sorbents were used (hydrated lime with activated carbon, hydrated lime with mineral sorbent). A summary of the materials used is shown in Table 1. The materials were injected in various rates to determine the correlation, on the basis of which dose rates for full scale installations will be determined. However, the impact of used sorbent onto fly ash wasn't investigated within the frame of this test. Hydrate lime helps to remove the problem of $\mathrm{SO}_{3}$, which limits the adsorption of $\mathrm{Hg}$ on activated carbons by occupying active sites available on the surface of carbon, this increase the absorption efficiency.

a)

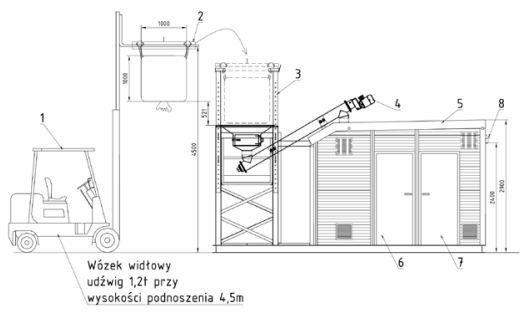

b)

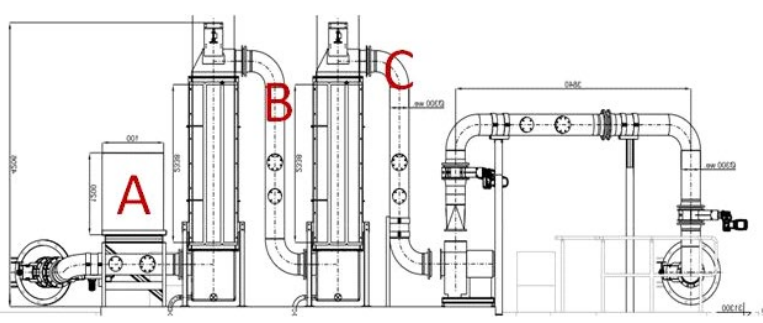

Fig. 5. A simplified diagram of the planned pilot installation: a) sorbent injection, b) GORE modules

Rys. 5. Uproszczony schemat planowanej instalacji pilotażowej a) wtrysk sorbentu, b) moduły GORE

TABLE 1. Sorbents used during pilot tests

TABELA 1. Sorbenty użyte do testów

\begin{tabular}{|l|l|l|}
\hline The commercial name of the sorbent & \multicolumn{1}{|c|}{ Manufacturer } & \multicolumn{1}{|c|}{ Composition } \\
\hline B-PAC+ & Albemarle & Activated carbon, bromine \\
\hline Darco Hg-LH Extra SR & Cabot & Activated carbon, bromine (4-6\%), silica \\
\hline Haloizyt & Intermark & Mineral granules - based on halloysite \\
\hline Sorbacal HS & Lhoist & $\mathrm{CaO}, \mathrm{MgO}, \mathrm{Ca}(\mathrm{OH})_{2}, \mathrm{CO}_{2}, \mathrm{SO}_{3}, \mathrm{SiO}_{2}, \mathrm{H}_{2} \mathrm{O}$ \\
\hline Sorbacal 35 & Lhoist & $\begin{array}{l}\text { Mixture of calcium hydroxide and activated carbon } \\
\text { (from 1 to max. 35\%) }\end{array}$ \\
\hline Carbosorb 15 & Elbar Katowice & $\begin{array}{l}\text { A mixture of calcium hydroxide and activated carbon } \\
\text { (from 1 to max. 15\%) }\end{array}$ \\
\hline Sorbacal HS + Haloizyt & Lhoist/Intermark & A mixture of Sorbacal HS and Haloisite (20\%) \\
\hline
\end{tabular}

New innovative materials such as zeolites can be an alternative to current sorbents. Considering zeolites sorbents within the frame of the presented analysis, synthetic zeolites of an X structure obtained from Class F fly ash were taken into account. Zeolites constitute porous, hydrated aluminosilicates of alkali elements, alkaline earth metals or other cations (Wdowin et al. 2014). Their specific properties, such as: thermal stability, ion exchange, molecular sieve and catalyst 
properties, make these materials useful for a variety of applications, among others as adsorbents for the removal of many environmental pollutants (Franus et al. 2014; Auerbach et al. 2003). It is known that zeolites are not good sorbents for the removal of the gaseous form of mercury (Wdowin 2015), therefore in order to increase their efficiency terms to $\mathrm{Hg}^{0}$ capture zeolites were modified with silver, iron and manganese ions. The different ions were used due to various cost of zeolites production.

\section{Economic efficiency analysis for mercury removal technology}

The assessment of the economic viability of the investment is therefore a very important element in the overall assessment of a given energy project in the field of mercury reduction. Establishing whether the investment is profitable or not, is the first step in the overall assessment of the company.

The reduction of mercury emissions from sorbent combustion processes is the result of implementing technology to control the emission of conventional pollutants (dust, $\mathrm{SO}_{2}$ and $\mathrm{NOx}$ ) and specific technologies for heavy metal removal. The unit costs of emission control are estimated as the cost per unit of mercury removed (PLN/kg Hg) or as the cost per unit of activity (PLN/MWh of electricity production).

The costs of reducing mercury emissions vary significantly depending on factors such as: the type of coal burned, type of combustion plant, types of other emission control technologies used, plant configuration and the expected percentage reduction of mercury emissions. The additional cost of controlling mercury emissions, expressed in monetary units per kg of mercury removed, will be high when:

$\checkmark$ the current level of emission control in existing aftertreatment systems is high,

$\checkmark$ the mercury content of coal is low because smaller amounts of mercury are removed from the flue gas at a certain level of their purification (Pacyna et al. 2008).

The project involves the construction of a pilot installation at Pątnów II Power Plant, which will allow data from real industrial processes to be obtained. The data will form the basis for conducting an economic viability analysis for three different technologies: GORE, hybrid configuration and sorbent injection. Elements of the designed technology are both commonly used mercury reduction techniques, including innovative solutions based on polymeric membrane modules, as well as the method of sorbent injection and dosing of fuel additives.

The economic efficiency analysis included operational expenditure (OPEX) and capital expenditure (CAPEX).

OPEX (operating expenditures) are expenses incurred for maintaining and implementing the functions of the enterprise. They may apply to the product, department or entire systems. These are typical operating costs, which in most cases are tax deductible costs. 
The concept related to OPEX is CAPEX. CAPEX (capital expenditures) - means capital expenditure on product development or system implementation - but only in the part where capital is allocated to maintaining the company's current ability to generate income.

CAPEX expenditure includes the sums spent on:

$\downarrow$ purchases of fixed and intangible assets,

४ repairing existing assets to increase their usability,

$\downarrow$ modernization of assets held,

$\downarrow$ preparation of assets for use in the business,

$\downarrow$ adapting real estate or assets for other uses,

$\checkmark$ starting a new business or taking over another business.

The differences between OPEX and CAPEX relate primarily to their accounting and tax treatment. CAPEX is not included in the cost of doing business and cannot be fully tax deductible in the period in which it was incurred. Only the depreciation installments associated with the asset for which the expenditure was incurred are subject to tax deduction. On the other hand, OPEX is treated as the cost of doing business and can be fully tax deductible.

In accounting terms, the difference relates to assets. CAPEX is expenditure incurred in connection with the assets themselves, and in OPEX it is related to the processes of their use.

Data for economic analysis was obtained from SBB Energy SA and Pątnów Power Plant II.

The following assumptions were used in the initial cost-effectiveness analyses:

$\checkmark$ capital expenditure depends on the technology used,

$\downarrow$ only expenses for the purchase of sorbents and thet depreciation of fixed assets at the level of $7 \%$ were included in the OPEX costs,

$\checkmark$ system operation time ( $24 \mathrm{~h} /$ day, with a two-week break - $8424 \mathrm{~h} /$ year),

$\checkmark$ the cost assessment is carried out on the basis of data in force for the zero moment,

$\downarrow$ the time covered by the analysis is calculated in full years.

Capital expenditures (CAPEX) are highest for maintenance-free GORE technologies - PLN 69 million. Another associated hybrid configuration is PLN 35 million. The least expensive of them is an innovative solution that is the subject of the project - technology based on sorbent injection, without the use of GORE modules (PLN 5 million, Fig. 6).

The next step was to estimate the costs incurred to maintain the above technologies (OPEX). Four raw materials were analyzed, i.e. brominated activated carbon from Cabot, silver, iron and manganese modified zeolites. The highest price is silver-modified zeolite (PLN 16/kg), and the lowest price is manganese-modified zeolite (PLN 6.4/kg). Their average quantity in terms of $\mathrm{kg} / \mathrm{h}$ was also assumed. For Cabot carbon it is $175 \mathrm{~kg} / \mathrm{h}$, and for zeolites $87.5 \mathrm{~kg} / \mathrm{h}$ (Table 2).

The highest annual cost of raw material was for Cabot brominated activated carbon (PLN 13.3 million), and then for silver-modified zeolite (PLN 11.8 million, Fig. 7), both per annum. It should be noted that the low prices of zeolites result from the fact of their recovery from ash, which is waste. Ash is produced in an amount of 6.9 million $\mathrm{Mg} /$ year.

The obtained data allowed the valuation of additional OPEX costs, which were included in the analysis, i.e. depreciation of each of the proposed technologies and water costs needed to 


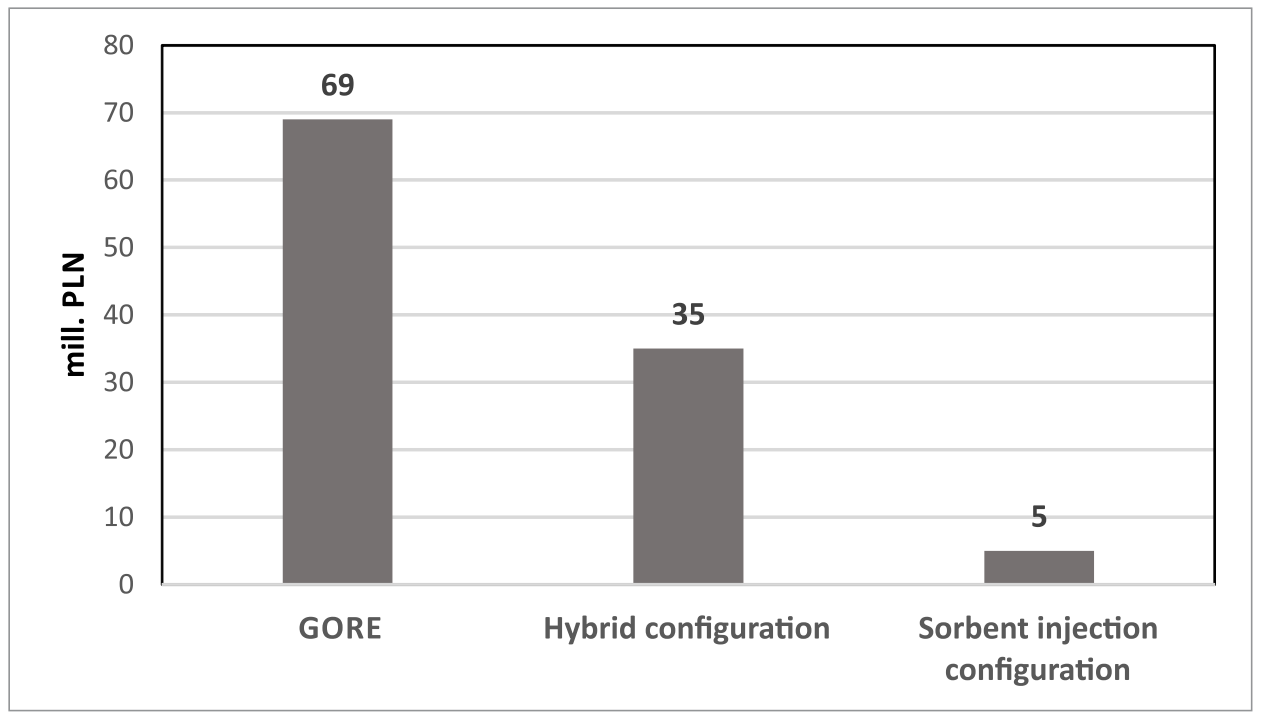

Fig. 6. Capital expenditure on mercury removal technology [in million PLN] (own study based on SBB Energy SA and Pątnów II Power Plant)

Rys. 6. Nakłady inwestycyjne technologii usuwania rtęci [mln PLN]

TABLE 2. Price and quantity of raw materials needed for the operation of mercury removal

TABELA 2. Cena i ilość surowców potrzebnych do funkcjonowania technologii usuwania rtęci

\begin{tabular}{|l|c|c|c|}
\hline \multicolumn{1}{|c|}{ Raw Materials } & $\begin{array}{c}\text { Price } \\
{[\text { in PLN/kg] }}\end{array}$ & $\begin{array}{c}\text { Quantity } \\
{[\mathrm{kg} / \mathrm{h}]}\end{array}$ & $\begin{array}{c}\text { Average accepted quantity of raw material } \\
{[\mathrm{kg} / \mathrm{h}]}\end{array}$ \\
\hline Activated carbon cabot & 9.0 & $100-250$ & 175.0 \\
\hline Silver modified zeolite & 16.0 & $50-125$ & 87.5 \\
\hline Iron-modified zeolite & 8.0 & $50-125$ & 87.5 \\
\hline Manganese modified zeolite & 6.4 & $50-125$ & 87.5 \\
\hline
\end{tabular}

Source: own study based on SBB Energy SA and Pątnów II Power Plant.

clean the modules, i.e. PLN 100 thousand/year for GORE technology and PLN 50 thousand/year for hybrid configuration (Fig. 8).

The statement of CAPEX and OPEX costs is the highest in the case of GORE due to the high cost of purchasing technology (PLN 69 million). Another is the hybrid configuration in the range of PLN 50.8-42.2 million depending on the sorbent used. The lowest ones concern the sorbent injection configuration (PLN 18.6-10.1 million, Fig. 9).

The last part of the analysis concerned the estimation of CAPEX and OPEX costs for removing $1 \mathrm{~kg}$ of mercury in the three above mercury removal technologies. At Pątnów II Power 


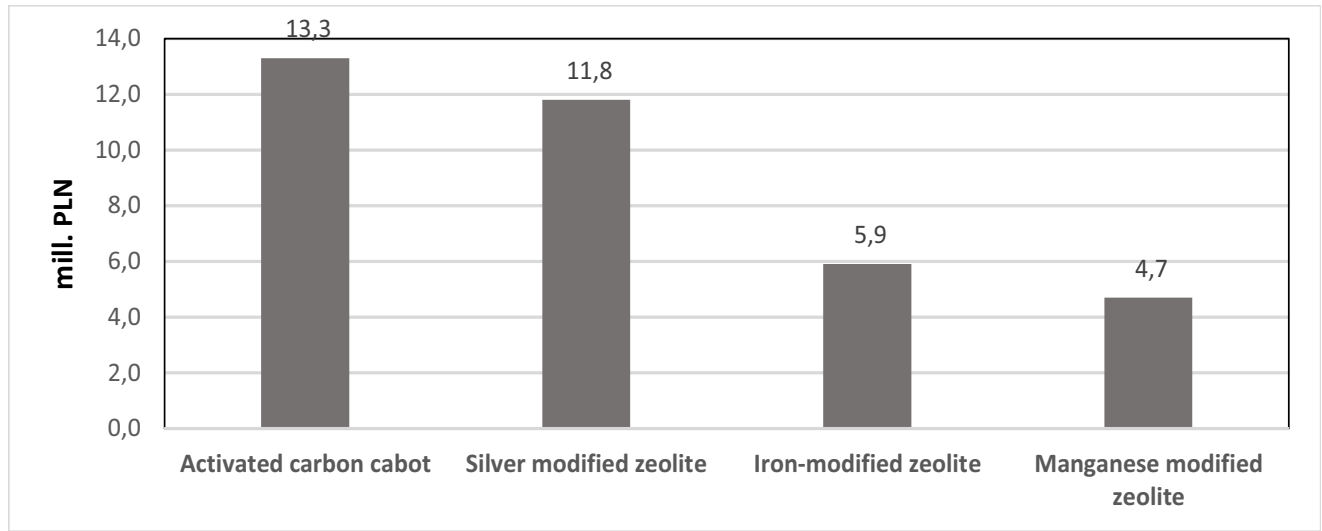

Fig. 7. The raw material costs needed for the operation of mercury removal technology on an annual basis [in million PLN] (own study based on SBB Energy SA and Pątnów II Power Plant)

Rys. 7. Koszty surowca potrzebnych do funkcjonowania technologii usuwania rtęci w ujęciu rocznym [mln PLN]

Plant, the mercury emitted exceeds the norm by $7 \mathrm{mg} / \mathrm{m}^{3}$. The amount of exhaust gas entering the atmosphere is 1.9 million $\mathrm{m}^{3}$. The installation works $8424 \mathrm{~h} /$ year. This means that the level of mercury emitted annually is $80,028 \mathrm{~kg}$.

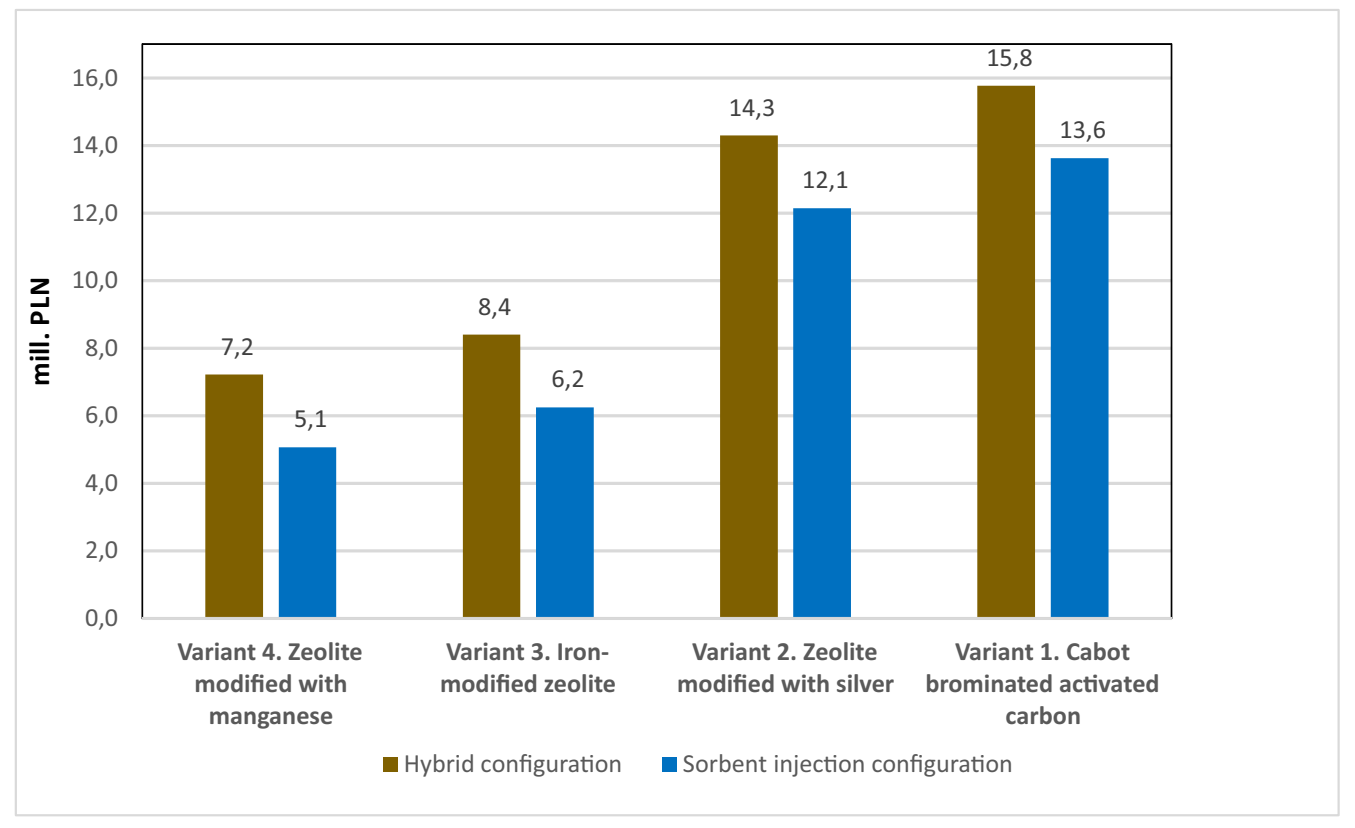

Fig. 8. The OPEX costs of hybrid configuration technology and sorbent injection on an annual basis [in million PLN] (own study based on SBB Energy SA and Pątnów II Power Plant)

Rys. 8. Koszty OPEX technologii konfiguracji hybrydowej i wtrysku sorbentu w ujęciu rocznym [mln PLN] 


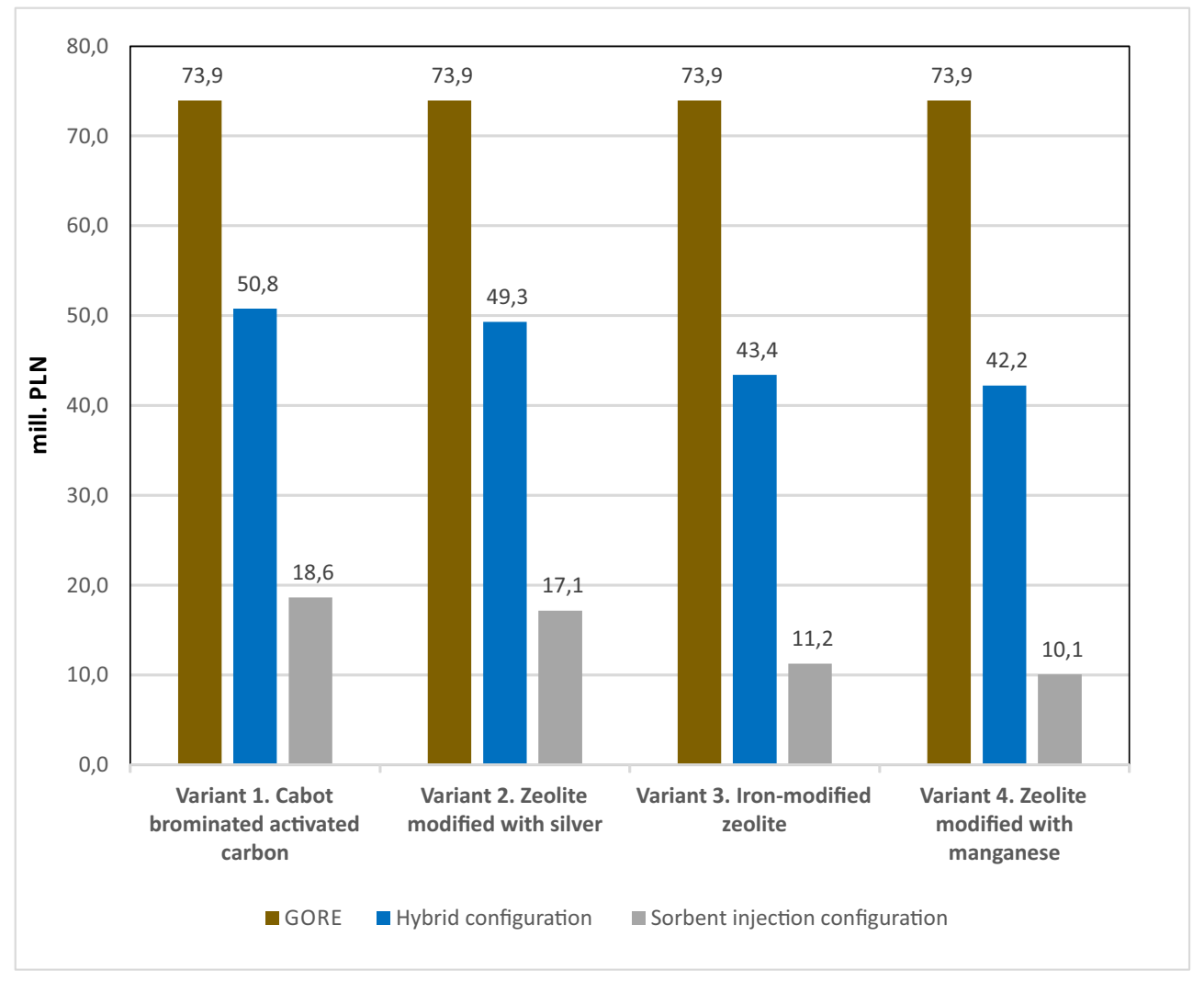

Fig. 9. Comparison of CAPEX and OPEX costs of mercury removal technology on an annual basis [in million PLN] (own study based on SBB Energy SA and Pątnów II Power Plant)

Rys. 9. Zestawianie kosztów CAPEX i OPEX technologii usuwania rtęci w ujęciu rocznym [mln PLN]

The statement of CAPEX and OPEX costs and the quantity of mercury emitted allowed for the estimation of the emission price of $1 \mathrm{~kg}$ of mercury (Table 3 ).

TABLE 3. Cost of $1 \mathrm{~kg}$ mercury removal by selected technologies using various sorbents [in PLN]

TABELA 3. Cena emisji rtęci w technologiach usuwania rtęci z zastosowaniem różnych sorbentów [PLN]

\begin{tabular}{|l|c|c|c|}
\hline \multicolumn{1}{|c|}{ Raw Materials } & GORE & $\begin{array}{c}\text { Hybrid } \\
\text { configuration }\end{array}$ & $\begin{array}{c}\text { Sorbent injection } \\
\text { configuration }\end{array}$ \\
\hline Variant 1. Activated carbon cabot & 924 & 634 & 233 \\
\hline Variant 2. Silver modified zeolite & 924 & 616 & 214 \\
\hline Variant 3. Iron-modified zeolite & 924 & 542 & 141 \\
\hline Variant 4. Manganese modified zeolite & 924 & 528 & 126 \\
\hline
\end{tabular}

Source: own study. 
GORE technology should be considered the most expensive variant. In the case of hybrid configuration technology and injection of sorbent, Cabot brominated activated carbon was the most expensive, another one modified (PLN 19) is silver modified zeolite. The least expensive option is sorbent injection technology using manganese-modified zeolite. It is less expensive than the most expensive variant eight times.

\section{Conclusion}

In the next 2 years, large power plants will be required to meet stringent emission limits. These plants may be required to install additional technologies to remove mercury from the flue gas. It is estimated that by 2022 mercury emissions from energy production should decrease to below $9 \mathrm{Mg}$ per year, compared to $15.5 \mathrm{Mg}$ in 2013. Emissions in 2022 may be as high as $2.5 \mathrm{Mg}$ if all EU Member States apply the most ambitious limits.

Currently, only one mercury reduction technology has been used in lignite power plants in Europe and it's based on the injection of activated carbons (solid sorbents). However, more installations of removal technologies are expected when BAT conclusions are implemented.

Preliminary analysis shows that the system of proposed technologies is very cost-competitive compared to GORE technology as stand-alone technology. The basic factors are the possibility of recovering zeolites from ash, combined with low capital expenditure (hybrid configuration 35 million PLN, sorbent injection - PLN 5 million).

OPEX costs in hybrid configuration are higher compared to sorbent injection as only one solution. This is mainly due to higher depreciation costs. In each of the analyzed variants (Cabot carbon, silver, iron or manganese modified zeolites), technology with the usage of sorbent injection is the most effective.

The most expensive variant should be GORE technology - the ratio of CAPEX and OPEX costs to the amount of mercury emitted $(80,028 \mathrm{~kg})$. In the case of hybrid configuration technology and sorbent injections, Cabot brominated activated carbon was the most expensive, another one is silver modified zeolite. The least expensive option is sorbent injection technology using manganese-modified zeolite. It is less expensive than the most expensive variant eight times.

This work was financed by the National Centre for Research and Development program Lider contract number LIDER/384/L-6/14/NCBR/2015 as well as construction of hybrid installation within frame of program PBSE No. of contract POIR.01.02.00-00-0198. 


\section{References}

AMAP/UNEP 2018. Technical Background Report for the Global Mercury Assessment Arctic Monitoring and Assessment Programme 2018, Oslo, Norway/UNEP Chemicals Branch, Geneva, Switzerland.

Assessment of mercury air pollution at regional stations in Poland in 2016 (Ocena zanieczyszczenia powietrza rtęcia na stacjach tta regionalnego w Polsce za 2016 r.) Chief Inspectorate Of Environmental Protection (Główny Inspektorat Ochrony Środowiska), Warszawa 2017 (in Polish).

Auerbach et al. 2003 - Auerbach, S.M., Carrado, K.A. and Dutta, P.K. 2003. Handbook of Zeolite Science and Technology. Marcel Dekker Inc. 25-30.

Directive 2000. Directive 2000/76/EC Of The European Parliament And Of The Council of 4 December 2000 on the incineration of waste.

Directive 2001. Directive 2001/80/EC Of The European Parliament And Of The Council of 23 October 2001 on the limitation of emissions of certain pollutants into the air from large combustion plants.

Directive 2008. Directive 2008/1/EC Of The European Parliament And Of The Council of 15 January 2008 concerning integrated pollution prevention and control.

Directive 2010. Directive 2010/75/EU Of The European Parliament And Of The Council of 24 November 2010 on industrial emissions (integrated pollution prevention and control).

Directive 96. Council Directive 96/61/EC of 24 September 1996 concerning integrated pollution prevention and control directive 2000/76/EC Of The European Parliament And Of The Council of 4 December 2000 on the incineration of waste.

EFA 2018. Mercury in Europe's environment A priority for European and global action, EEA, Copenhagen.

EPA 2020. [Online] https://www.epa.gov/ [Accessed: 2020-01-15].

Franus W. et al. 2014 - Franus, W., Wdowin, M. and Franus, M. 2014. Synthesis and characterization of zeolites prepared from industrial fly ash. Environmental Monitoring and Assessment 186, pp. $5721-5729$.

GORE 2020. [Online] www.gore.com [Accessed: 2020-02-15].

IPCS 2000. International Chemical Safety Cards 0056, 0978, 0979, 0980, 0981, 0982 and 0984. Geneva, World Health Organization, International Programme on Chemical Safety.

LELEK, Ł. and WDOwIN, M. 2016. Environmental aspects of the use of Type X modified zeolite from fly ash to capture mercury in a life cycle perspective (Środowiskowe aspekty zastosowania modyfikowanego zeolitu typu $X$ z popiołów lotnych do wychwytywania rtęci w perspektywie cyklu życia). Zeszyty Naukowe Instytutu Gospodarki Surowcami Mineralnymi i Energia Polskiej Akademii Nauk No. 95, pp. 117-128 (in Polish).

LORENZ, U. and GRUDZIŃSKI, Z. 2007. Mercury content as a potential factor limiting the utility value of hard coal and lignite (Zawartość rtęci jako potencjalny czynnik ograniczajacy wartość użytkowa węgla kamiennego i brunatnego). Górnictwo i Geoinżynieria 3/1, pp. 335-349 (in Polish).

LRTAP 2017. European Union emission inventory report 1990-2015 under the UNECE Convention on Long-range Transboundary Air Pollution (LRTAP).

Pacyna E.G. et al. 2010 - Pacyna, E.G., Pacyna, J.M., Sundseth, K., Munthe, J., Wilson, S., SteenHUISEN, F. and MAXsON, P. 2010. Global emission of mercury to the atmosphere from anthropogenic sources in 2005 and projections to 2020. Atmospheric Environment Vol. 44, Iss. 20, June 2010, pp. $2487-2499$.

Pacyna J.M. et al. 2008 - Pacyna, J.M., Sundseth, K., Pacyna, E.G., Munthe, J., Belhaj, M., Astrom, S., Panasiuk, D. and Glodek, A. 2008. UNEP Report on A general qualitative assessment of the potential costs and benefits associated with each of the strategic objectives set out in Annex 1 of the report of the first meeting of the Open Ended Working Group (Raport UNEP w sprawie Ogólnej oceny 
jakościowej potencjalnych kosztów i korzyści zwiąanych z każdym z celów strategicznych określonych $w$ załaczniku 1 do sprawozdania z pierwszego spotkania grupy roboczej), UNEP-CBA Report (in Polish).

Polish Electricity Committee 2018. The contribution of the Polish energy sector to the implementation of global climate policy (Wklad polskiego sektora energetycznego w realizacje globalnej polityki klimatycznej), Warszawa (in Polish).

Senior et al. 2000 - Senior, C.L., Helble, J.J. and SArofim, A.F. 2000. Emissions of mercury, trace elements, and fine particles from stationary combustion sources. Fuel Processing Technology 65-66, pp. 263-288.

UNECE 2016. European Union emission inventory report 1990-2015 under the UNECE Convention on Long-range Transboundary Air Pollution (LRTAP).

UNEP 2013, Mercury Time to act. [Online] < http://content.yudu.com/A20ki2/MercuryTimetoAct/resources/index.htm $>$ [Accessed: 2013-06-11].

Wdowin, M. 2015. Po angielski.... (Zastosowanie zeolitów do separacji $\mathrm{CO}_{2}$ i $\mathrm{Hg}$ z gazów odlotowych w procesach wychwytywania i sktadowania ditlenku węgla). Monografie No. 120, Lublin, 199 p.

Wdowin et al. 2014b - Wdowin, M., Franus, M., Panek, R., Badura, L. and Franus, W. 2014b. The conversion technology of fly ash into zeolites. Clean Techn. Environ. Policy 16, pp. 1217-1223.

Wichliński M. et al. 2017 - Wichliński, M., Wielgosz, G. i KobYŁeCKI, R. 2017. Mercury emissions from polish pulverized coal fired boiler (Emisje rtęci z polskiego kotła pyłowego na wegiel). E3S Web of Conferences 14, 02008, pp. 1-8.

Żmuda R. et al. 2017 - Żmuda, R., Adamczyk, W., Lelek, Ł., Mandrela, S. and Wdowin, M. 2017. Innovative mercury flue gas treatment technology as a solution to meet the requirements of the BAT/BREF conclusions in the Polish energy sector (Innowacyjna technologia oczyszczania spalin z rtęci jako rozwiazanie sprostania wymogom stawianym przez konkluzje BAT/BREF $w$ polskiej energetyce). Polityka Energetyczna - Energy Policy Journal Vol. 20, Iss. 4 (in Polish).

Renata Koneczna, Robert ŻMuda, Łukasz LeleK, Magdalena Wdowin

\section{Analiza opłacalności ekonomicznej zastosowania sorbentów zeolitowych w technologiach usuwania $\mathrm{Hg}$}

\section{Streszczenie}

Emisja rtęci w ostatnich latach stała się jednym z problemów sektora energetycznego. Obecnie stosowane techniki usuwania rtęci to: metody pierwotne, wtórne i wstępne. Nie są one wystarczająco skuteczne, aby spełnić nowe wymagania określone przez BREF/BAT, dlatego konieczne jest poszukiwanie nowych, wysokowydajnych rozwiązań. Propozycja nowej technologii została opracowana w ramach projektu „Hybrydowe systemy adsorpcyjne w celu zmniejszenia emisji rtęci za pomocą wysoce skutecznych składników polimerowych" (HYBREM). Projekt został zrealizowany przez konsorcjum SBB Energy SA i Elektrownię Pątnów II. W jego ramach zbudowano innowacyjną, wysokowydajną technologię do oczyszczania gazów 
spalinowych z rtęci. Zastosowano technologię GORE, która łączy istniejące rozwiązania wykorzystujące wydajne moduły polimerowe oraz system wtrysku stałego sorbentu. Innym rozwiązaniem jest technologia konfiguracji wtrysku sorbentu bez użycia modułów GORE. Aby ocenić efektywność ekonomiczną dla przypadku podobnego jak w projekcie HYBREM, wybrano model oparty na OPEX i CAPEX. Artykuł koncentruje się na zastąpieniu stałych sorbentów stosowanych w projekcie HYBREM materiałami na bazie zeolitów. Zastosowany w projekcie zmodyfikowany zeolit X pochodził z popiołu lotnego. Wstępna analiza pokazuje, że system proponowanych technologii jest bardzo konkurencyjny pod względem kosztów w porównaniu z technologią GORE. Podstawowym czynnikiem sukcesu jest możliwość odzyskiwania zeolitów z popiołu w połączeniu z niskimi nakładami inwestycyjnymi.

SŁoWA KLUCZOWE: technologie usuwania rtęci, analiza ekonomiczna, studium przypadku, koszty inwestycji, koszty operacyjne 